\title{
ENZYME CATALYTIC RESONANCE SCATTERING SPECTRAL DETECTION OF TRACE HYDROGEN PEROXIDE USING GUAIACOL AS SUBSTRATE
}

\author{
Huixiang Ouyang ${ }^{1,2,3}$, Shiwen Huang ${ }^{1,2,3}$ and Zhiliang Jiang ${ }^{1,2,3^{*}}$ \\ ${ }^{1}$ Key Laboratory of Ecology of Rare and Endangered Species and Environmental Protection, \\ Ministry of Education, China \\ ${ }^{2}$ Guangxi Key Laboratory of Environmental Engineering, Protection and Assessment, Guilin \\ 541004, China \\ ${ }^{3}$ Guangxi Normal University, Guilin 541004, China
}

(Received July 23, 2010; revised November 8, 2010)

\begin{abstract}
Hydrogen peroxide oxidized guaiacol to form tetramer particles that exhibited a strong resonance scattering (RS) peak at $530 \mathrm{~nm}$ in the presence of horseradish peroxidase (HRP) in citric acid-Na $\mathrm{HPO}_{4}$ buffer solution of $\mathrm{pH} 4.4$. The RS peak increased when the concentration of hydrogen peroxide increased. The increased RS intensity $\left(\Delta \mathrm{I}_{530 \mathrm{~nm}}\right)$ was linear to the hydrogen peroxide concentration in the range of $0.55-27.6 \mu \mathrm{M}$, with a linear regression equation of $\Delta \mathrm{I}_{530 \mathrm{~nm}}=17.1 C+1.6$, a relative coefficient of 0.9996 and a detection limit of 0.03 $\mu \mathrm{M} \mathrm{H} \mathrm{H}_{2} \mathrm{O}_{2}$. This proposed method was applied to detect hydrogen peroxide in rain water, with sensitivity, selectivity, rapidity, and recovery of 98.0-104\%.
\end{abstract}

KEY WORDS: HRP, $\mathrm{H}_{2} \mathrm{O}_{2}$, Guaiacol, Resonance scattering spectral method

\section{INTRODUCTION}

Hydrogen peroxide is an important strong oxidant, sterilant, and disinfectant, and it is a main composition of acid rain [1]. After hydrogen peroxide disinfecting or acid rain, there are undecomposed hydrogen peroxide that can threaten to people's health. So, it is essential to determination of trace hydrogen peroxides in environmental, chemical, biological and clinical fields [2]. At present, the main assays for detecting the trace hydrogen peroxide include high performance liquid chromatography [3, 4], chemiluminescence [5, 6], fluorescence [7, 8], atomic absorption spectrometry [9, 10], spectrophotometry [11, 12], flow injection [13, 14], and resonance scattering spectrometry $[15,16]$ methods. Light scattering phenomenon commonly exists in the interaction between photon and particle. It plays a very important role in the research areas of photonics, colloid chemistry and polymer chemistry. Resonance scattering technique has been established by Pasternack et al. [17] in 1993 with a conventional fluorescence spectrophotometer, and have been utilized to study molecular recognition, assemblies and aggregates with sensitivity. In 1990's, Liu [18] and Huang [19] expanded the application scope of resonance scattering technique, and used it in inorganic and nucleic acid analysis. Since 1998, our research group discovered the resonance scattering effect of some nanoparticles including metal, nonmetal and semiconductor, and it was combined with associated reaction, catalytic reaction, immune reaction and aptamer reaction to establish the corresponding RS methods [20-23]. However, there is no report about organic particle RS effect and RS study of $\mathrm{H}_{2} \mathrm{O}_{2}$-guaiacol-HRP catalytic system. In this article, we study the organic particle system with RS technique, and a new RS method has been set up for the determination of $\mathrm{H}_{2} \mathrm{O}_{2}$.

\footnotetext{
*Corresponding author. E-mail: zljiang@mailbox.gxnu.edu.cn
} 


\section{EXPERIMENTAL}

Apparatus and reagents

A Cary Eclipse spectrofluorometer (Varian, USA) and a Zetasizer Nano ZS90 (Malvern, UK) were used.

A $500 \mu \mathrm{g} / \mathrm{mL}$ HRP (biochemical reagent, $\mathrm{RZ}\left[=\mathrm{A}_{403 \mathrm{~nm}} / \mathrm{A}_{275 \mathrm{~nm}}\right]$ more than 3, $300 \mathrm{U} / \mathrm{mg}$, Huamei Biological Engineering Co.) was prepared by dissolving $5.0 \mathrm{mg} \mathrm{HRP}$ to $10 \mathrm{~mL}$ with water, and was stored in $4{ }^{\circ} \mathrm{C}$ refrigerator. $\mathrm{A}_{2} \mathrm{O}_{2}$ solutions $\left(8.27 \times 10^{-2} \mathrm{M}\right)$ were standardized by using $\mathrm{KMnO}_{4}$ standard solution. The pH 4.4 citric acid $\left(\mathrm{C}_{6} \mathrm{H}_{8} \mathrm{O}_{7}\right)-\mathrm{Na}_{2} \mathrm{HPO}_{4}$ buffer solution was prepared by mixing of $11.2 \mathrm{~mL} 0.1 \mathrm{M}$ citric acid and $8.8 \mathrm{~mL} 0.1 \mathrm{M} \mathrm{Na}_{2} \mathrm{HPO}_{4}$ solutions. The $\mathrm{pH}$ buffer solutions of $\mathrm{C}_{6} \mathrm{H}_{8} \mathrm{O}_{7}-\mathrm{C}_{6} \mathrm{H}_{5} \mathrm{O}_{7} \mathrm{Na}_{3}$, $\mathrm{HAc}-\mathrm{NaAc}$ and $\mathrm{HCl}-\mathrm{NaAc}$ were prepared by mixing of $0.1 \mathrm{M}$ corresponding both components according to a certain volume ratio. A $2 \times 10^{-4} \mathrm{M}$ guaiacol solution was prepared. All the reagents were of analytical grade except explained and all the solutions were prepared with double-distilled water.

\section{Procedure}

A $0.2 \mathrm{~mL}$ pH $4.4 \mathrm{C}_{6} \mathrm{H}_{8} \mathrm{O}_{7}-\mathrm{NaH}_{2} \mathrm{PO}_{4}$ buffer solution, a $0.1 \mathrm{~mL} 2 \times 10^{-4} \mathrm{M}$ guaiacol solution, a certain amount of $\mathrm{H}_{2} \mathrm{O}_{2}, 100 \mu \mathrm{L} 5 \mu \mathrm{g} / \mathrm{mL}$ HRP solution were pipetted into a $5 \mathrm{~mL}$ marked tube, mixed well and diluted to $1.5 \mathrm{~mL}$ with water. Then it was put into water-bath at $37{ }^{\circ} \mathrm{C}$ for 30 min. The RS spectrum was scanned synchronously $\left(\lambda_{\mathrm{em}}-\lambda_{\mathrm{ex}}=0 \mathrm{~nm}\right)$ on fluorescence spectrophotometer with the excited and emission slit width of $5.0 \mathrm{~nm}$, and the PMT voltage of $400 \mathrm{~V}$. The RS intensity at $530 \mathrm{~nm}\left(\mathrm{I}_{530 \mathrm{~nm}}\right)$ and a reagent blank $\mathrm{I}_{0}$ was recorded. The value of $\Delta \mathrm{I}_{530 \mathrm{~nm}}=\mathrm{I}_{530 \mathrm{~nm}}-\mathrm{I}_{0}$ was calculated.

\section{RESULTS AND DISCUSSION}

\section{Principle}

In $\mathrm{pH} 4.4 \mathrm{C}_{6} \mathrm{H}_{8} \mathrm{O}_{7}-\mathrm{NaH}_{2} \mathrm{PO}_{4}$ buffer solution, $\mathrm{HRP}$ catalyzed $\mathrm{H}_{2} \mathrm{O}_{2}$ to form $\bullet \mathrm{OH}$. Then it oxidize guaiacol to generate tetramer complex [24]. This tetramer complex molecules can aggregate into particles with an average size of $463 \mathrm{~nm}$ tested by Zetasizer Nano ZS90 (Figure 1). The particle exhibited a RS peak at $530 \mathrm{~nm}$, and the RS value was linear to the concentration of $\mathrm{H}_{2} \mathrm{O}_{2}$. On this basis, a new RS method for the quantification of $\mathrm{H}_{2} \mathrm{O}_{2}$ was established. The principal reactions were following:

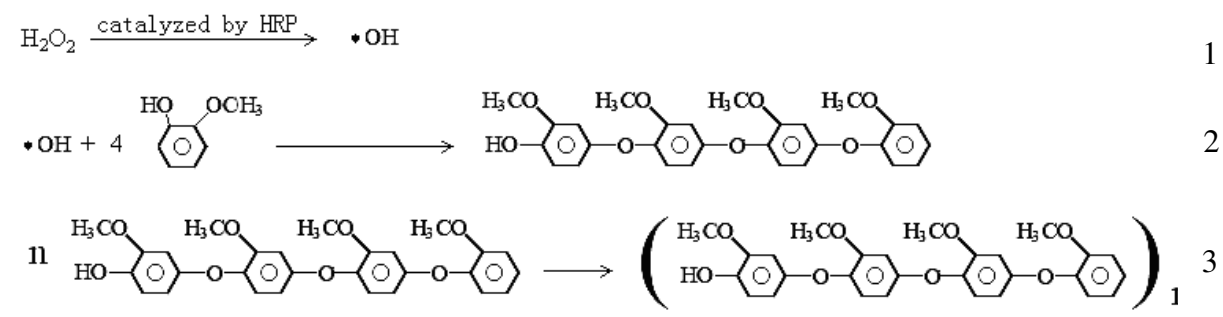

Bull. Chem. Soc. Ethiop. 2011, 25(2) 


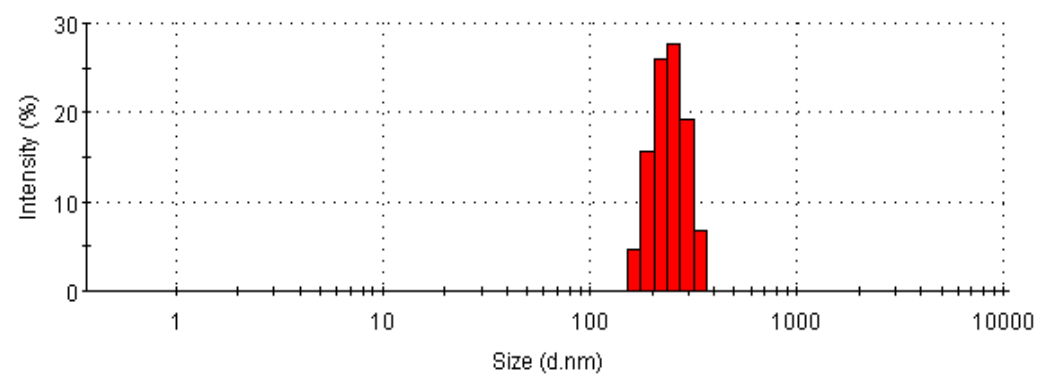

Figure 1. Laser scattering image of $\mathrm{C}_{6} \mathrm{H}_{8} \mathrm{O}_{7}-\mathrm{Na}_{2} \mathrm{HPO}_{4}$-guaiacol- $\mathrm{H}_{2} \mathrm{O}_{2}$ - $\mathrm{HRP}$ system.

RS spectra

The scattering signal of the $\mathrm{C}_{6} \mathrm{H}_{8} \mathrm{O}_{7}-\mathrm{Na}_{2} \mathrm{HPO}_{4}$, guaiacol, HRP systems is very weak. When a certain $\mathrm{H}_{2} \mathrm{O}_{2}$ was added into the system of $\mathrm{C}_{6} \mathrm{H}_{8} \mathrm{O}_{7}-\mathrm{Na}_{2} \mathrm{HPO}_{4}$-guaiacol-HRP, the catalytic oxidation reaction taken place rapidly, and formed tetramer complex particle in dark brown color. There is a resonance scattering peak at $530 \mathrm{~nm}$ (Figure 2). The color becomes deeper and the RS value increased at $530 \mathrm{~nm}$ when $\mathrm{H}_{2} \mathrm{O}_{2}$ concentration increased. So, $530 \mathrm{~nm}$ was selected for use in this assay.

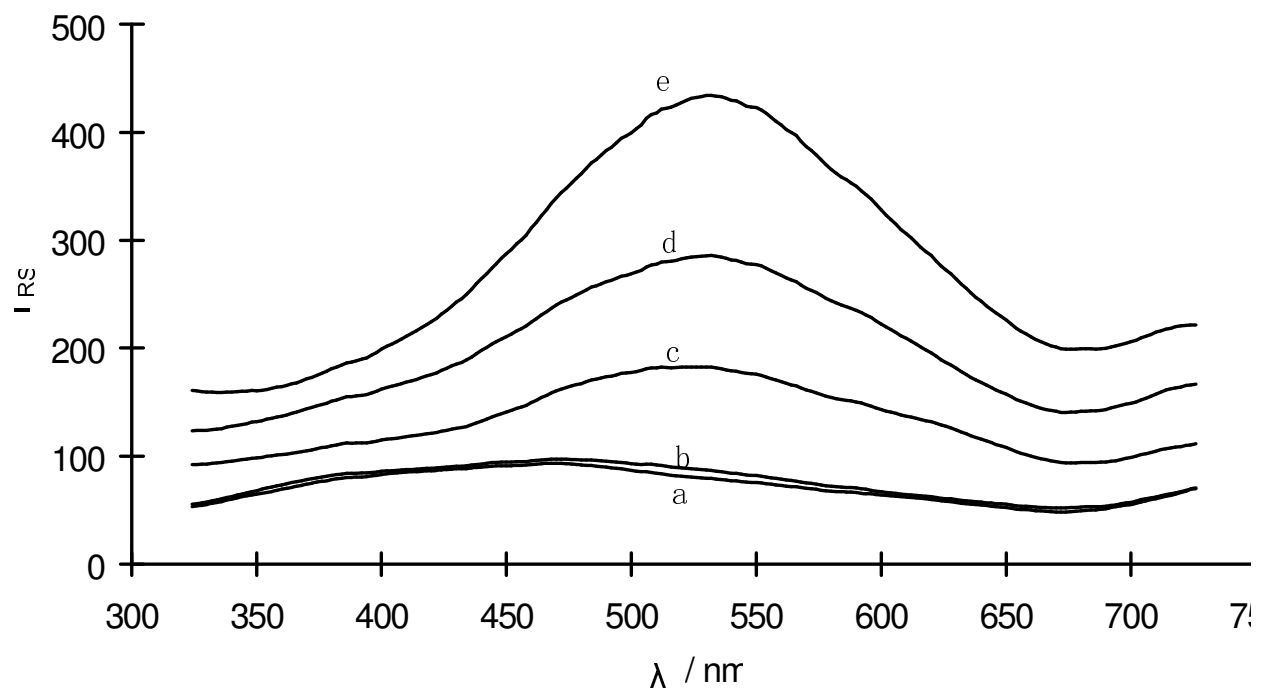

Figure 2. Resonance scattering spectra. a: $\mathrm{pH} 4.4 \mathrm{Na}_{2} \mathrm{HPO}_{4}-\mathrm{C}_{6} \mathrm{H}_{8} \mathrm{O}_{7}-1.33 \times 10^{-5} \mathrm{M} \mathrm{C}_{7} \mathrm{H}_{8} \mathrm{O}_{2}-0.33$ $\mu \mathrm{g} / \mathrm{mL}$ HRP; b: a - $1.1 \times 10^{-6} \mathrm{M} \mathrm{H}_{2} \mathrm{O}_{2}$; c: a - $5.51 \times 10^{-6} \mathrm{M} \mathrm{H}_{2} \mathrm{O}_{2} ; \mathrm{d}: \mathrm{a}-11.03 \times 10^{-6} \mathrm{M}$ $\mathrm{H}_{2} \mathrm{O}_{2}$; e: a $-27.56 \times 10^{-6} \mathrm{M} \mathrm{H}_{2} \mathrm{O}_{2}$.

\section{Effect of pH buffer solution}

The enzyme active part commonly contains acidic group and basic group, the catalytic reaction is very sensitive to the $\mathrm{pH}$ value, and its fitting $\mathrm{pH}$ range was narrow. As the $\mathrm{pH}$ value was changed, these groups were in different dissociation state, and the activity for HRP changed. 
Thus, HRP has its optimal $\mathrm{pH}$. The influence of four $\mathrm{pH}$ buffer solutions including $\mathrm{Na}_{2} \mathrm{HPO}_{4^{-}}$ $\mathrm{C}_{6} \mathrm{H}_{8} \mathrm{O}_{7}, \mathrm{C}_{6} \mathrm{H}_{8} \mathrm{O}_{7}-\mathrm{C}_{6} \mathrm{H}_{5} \mathrm{O}_{7} \mathrm{Na}_{3}$, HAc-NaAc, and $\mathrm{HCl}-\mathrm{NaAc}$ on the $\Delta \mathrm{I}_{530} \mathrm{~nm}$ was tested. Figure 3 showed that the sensitivity decreased in order of $\mathrm{Na}_{2} \mathrm{HPO}_{4}-\mathrm{C}_{6} \mathrm{H}_{8} \mathrm{O}_{7}, \mathrm{C}_{6} \mathrm{H}_{8} \mathrm{O}_{7}-\mathrm{C}_{6} \mathrm{H}_{5} \mathrm{O}_{7} \mathrm{Na}_{3}, \mathrm{HAc}-$ $\mathrm{NaAc}$, and $\mathrm{HCl}-\mathrm{NaAc}$. The $\mathrm{Na}_{2} \mathrm{HPO}_{4}-\mathrm{C}_{6} \mathrm{H}_{8} \mathrm{O}_{7}$ buffer solution is most sensitive, and was chosen for use. The $\Delta \mathrm{I}_{530 \mathrm{~nm}}$ reached maximum when the $\mathrm{pH}$ value was 4.4 that is its optimal $\mathrm{pH}$. Thus, a pH $4.4 \mathrm{Na}_{2} \mathrm{HPO}_{4}-\mathrm{C}_{6} \mathrm{H}_{8} \mathrm{O}_{7}$ buffer solution was chosen for use. The effect of buffer solution volume was suggested. When the volume of buffer solution was $0.2 \mathrm{~mL}$, the $\Delta \mathrm{I}_{530} \mathrm{~nm}$ was maximal. Thus, a $0.2 \mathrm{~mL} \mathrm{pH} 4.4 \mathrm{Na}_{2} \mathrm{HPO}_{4}-\mathrm{C}_{6} \mathrm{H}_{8} \mathrm{O}_{7}$ buffer solution was chosen.

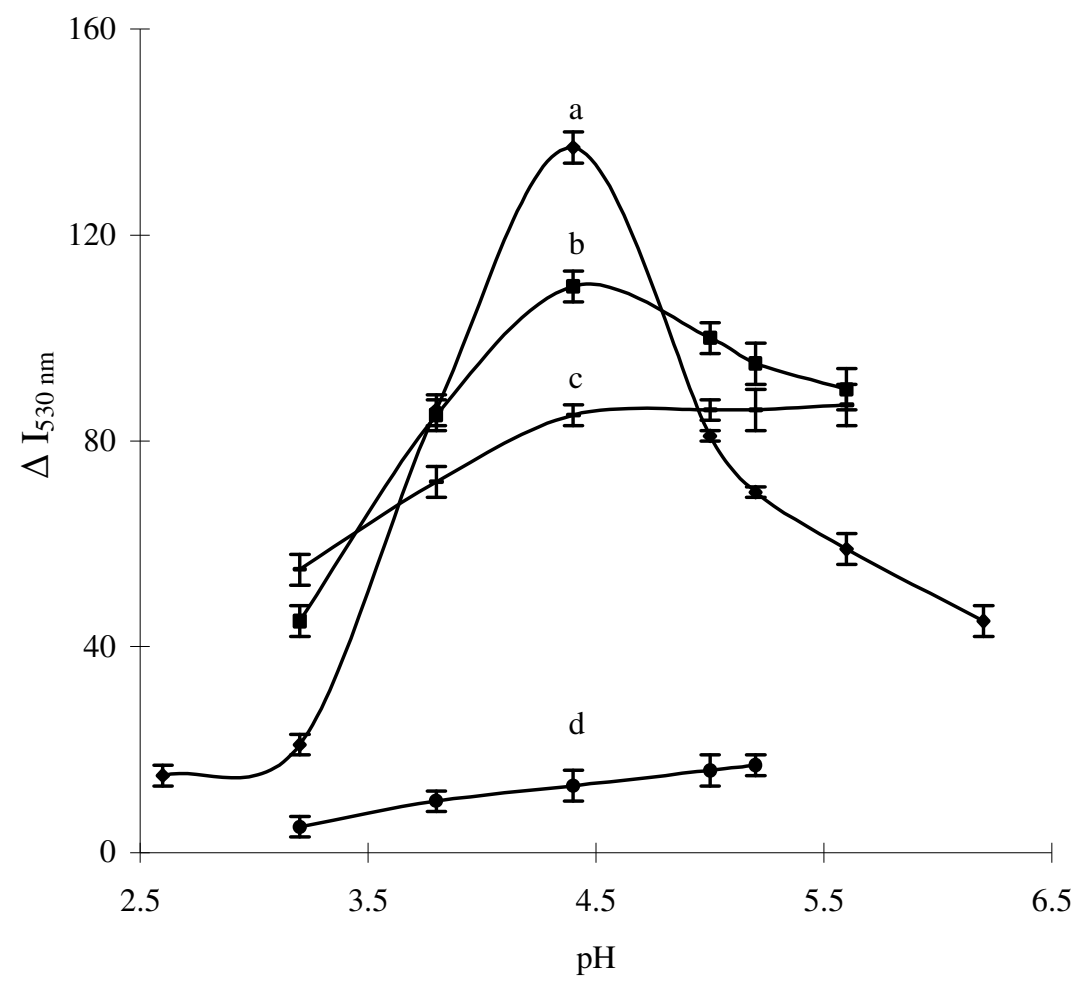

Figure 3. Effect of pH. a. $\mathrm{Na}_{2} \mathrm{HPO}_{4}-\mathrm{C}_{6} \mathrm{H}_{8} \mathrm{O}_{7}-1.33 \times 10^{-5} \mathrm{M}$ guaiacol-0.33 $\mu \mathrm{g} / \mathrm{mL}$ HRP-5.51 $\times$ $10^{-5} \mathrm{M} \mathrm{H}_{2} \mathrm{O}_{2}$; b. $\mathrm{C}_{6} \mathrm{H}_{8} \mathrm{O}_{7}-\mathrm{C}_{6} \mathrm{H}_{5} \mathrm{O}_{7} \mathrm{Na}_{3}-1.33 \times 10^{-5} \mathrm{M}$ guaiacol- $0.33 \mu \mathrm{g} / \mathrm{mL}$ HRP- $5.51 \times$ $10^{-5} \mathrm{M} \mathrm{H}_{2} \mathrm{O}_{2}$; c. HAc-NaAc- $1.33 \times 10^{-5} \mathrm{M}$ guaiacol- $0.33 \mu \mathrm{g} / \mathrm{mL} \mathrm{HRP}-5.51 \times 10^{-5} \mathrm{M}$ $\mathrm{H}_{2} \mathrm{O}_{2}$; d. HCl-NaAc- $\mathrm{C}_{6} \mathrm{H}_{8} \mathrm{O}_{7}-1.33 \times 10^{-5} \mathrm{M}$ guaiacol-0.33 $\mu \mathrm{g} / \mathrm{mL}$ HRP-5.51 $\times 10^{-5} \mathrm{M}$ $\mathrm{H}_{2} \mathrm{O}_{2}$.

\section{Effect of guaiacol}

With the concentration of guaiacol increasing, the $\Delta \mathrm{I}_{530 \mathrm{~nm}}$ value increased at first and then decreased slowly. The $\Delta \mathrm{I}_{530 \mathrm{~nm}}$ value was maximum when guaiacol was $1.33 \times 10^{-5} \mathrm{M}$. Thus, a $1.33 \times 10^{-5} \mathrm{M}$ guaiacol was chosen for use. 


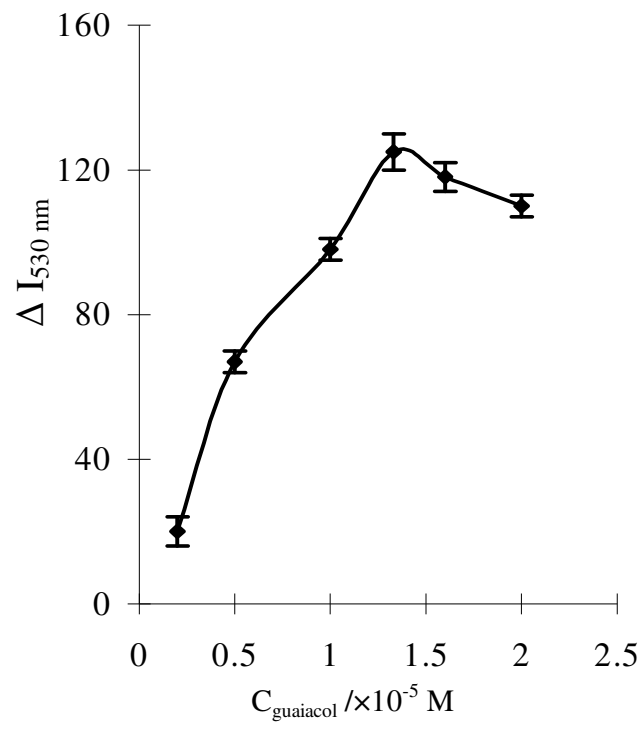

Figure 4. Effect of guaiacol concentration. $\mathrm{pH} 4.4 \mathrm{Na}_{2} \mathrm{HPO}_{4}-\mathrm{C}_{6} \mathrm{H}_{8} \mathrm{O}_{7}-0.33 \mu \mathrm{g} / \mathrm{mL}$ HRP-5.51 $\times$ $10^{-5} \mathrm{M} \mathrm{H}_{2} \mathrm{O}_{2}$.

\section{Effect of HRP}

The $\Delta \mathrm{I}_{530 \mathrm{~nm}}$ value of the system increased with HRP concentration increasing in the range of $0.05-0.3 \mu \mathrm{g} / \mathrm{mL}$, and then decreased as in Figure 5. The $\Delta \mathrm{I}_{530 \mathrm{~nm}}$ reaches the maximum when the concentration of HRP was $0.33 \mu \mathrm{g} / \mathrm{mL}$. Thus, $0.33 \mu \mathrm{g} / \mathrm{mL}$ HRP was chosen for use.

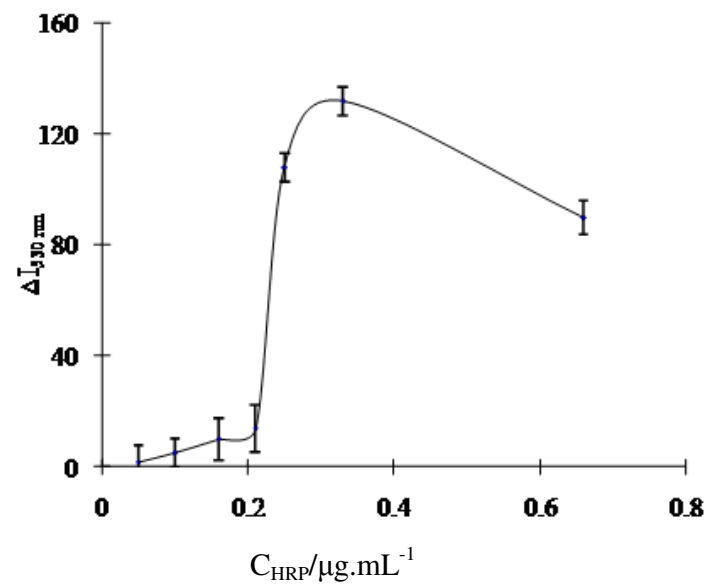

Figure 5. Effect of HRP concentration. $\mathrm{pH} 4.4 \mathrm{Na}_{2} \mathrm{HPO}_{4}-\mathrm{C}_{6} \mathrm{H}_{8} \mathrm{O}_{7}-1.33 \times 10^{-5} \mathrm{M}$ guaiacol-5.51 $\times$ $10^{-5} \mathrm{M} \mathrm{H}_{2} \mathrm{O}_{2}$. 
Effect of catalytic reaction time and temperature

In general, enzyme reaction has an optimal temperature, because high temperature resulted to enzyme denaturalization, and the velocity increased with the temperature. The effect of temperature on the HRP catalytic reaction is shown in Figure 6. The $\Delta \mathrm{I}_{530 \mathrm{~nm}}$ value reached maximum between $30-50{ }^{\circ} \mathrm{C}$. A $37{ }^{\circ} \mathrm{C}$ was chosen. Results showed that the $\Delta \mathrm{I}_{530 \mathrm{~nm}}$ value reached maximum when reaction time was $30 \mathrm{~min}$ and was stable for $50 \mathrm{~min}$. Thus, $30 \mathrm{~min}$ was selected for use.

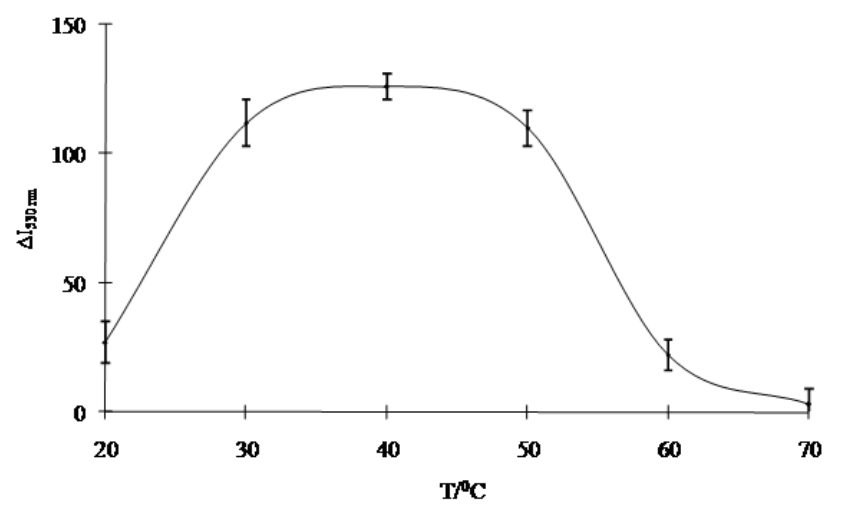

Figure 6. Effect of temperature. $\mathrm{pH} 4.4 \mathrm{Na}_{2} \mathrm{HPO}_{4}-\mathrm{C}_{6} \mathrm{H}_{8} \mathrm{O}_{7}-1.33 \times 10^{-5} \mathrm{M}$ guaiacol- $0.33 \mu \mathrm{g} / \mathrm{mL}$ $\mathrm{HRP}-5.51 \times 10^{-5} \mathrm{M} \mathrm{H}_{2} \mathrm{O}_{2}$.

\section{Influence of foreign substances}

According to the procedure, influences of some foreign substances including common metal cation and anion on the detection of $5.33 \mu \mathrm{M} \mathrm{H}_{2} \mathrm{O}_{2}$ were tested, with a relative error of $\pm 5 \%$. The results showed the tolerance limit as the following, 14 times of $\mathrm{Mg}^{2+}, 36$ times of $\mathrm{Ni}^{2+}$, $\mathrm{NO}_{2}{ }^{-}$may be coming from $\mathrm{NO}$ gas, and $\mathrm{Fe}^{3+}$ may be coming from dust, 60 times of $\mathrm{K}^{+}, \mathrm{Ca}^{2+}$ may be coming from dust, $\mathrm{NO}_{3}{ }^{-}, \mathrm{CO}_{3}{ }^{2-}$ may be coming from $\mathrm{CO}_{2}$ and dust, $\mathrm{SiO}_{3}{ }^{2-}$ may be coming from dust, $\mathrm{SO}_{4}{ }^{2-}$ may be coming from dust and $\mathrm{SO}_{3}$ gas, and $\mathrm{C}_{2} \mathrm{O}_{4}{ }^{2-}, 138$ times of $\mathrm{Li}^{+}$, 1200 times of $\mathrm{F}, 3900$ times of $\mathrm{NH}_{4}{ }^{+}$may be coming from $\mathrm{NH}_{3}$ gas do not interfere with the determination. The proposed RS assay had a good selectivity.

\section{Calibration curve}

According to the procedure, the calibration curve between $\mathrm{H}_{2} \mathrm{O}_{2}$ and $\Delta \mathrm{I}_{530 \mathrm{~nm}}$ was drawn, the linear range was $0.55-27.6 \mu \mathrm{M}$, with a regression equation of $\Delta \mathrm{I}_{530 \mathrm{~nm}}=17.1 \mathrm{C}+1.6$, a correlation coefficient of 0.9996 , and a detection limit (DL) of $0.03 \mu \mathrm{M}$. The DL can be calculated according to the equation $\mathrm{DL}=3 S_{\mathrm{b}} / K$, where 3 is the factor at the $95 \%$ confidence level, $S_{\mathrm{b}}$ the standard deviation of the blank measurements $(n=10)$, and $K$ is the slope of the calibration curve.

\section{Sample determination}

The autumnal rain water sample 1, 2 and 3 were collected in the place of urban (Sanlidian of Guilin city), rural (Caoping village of Guilin city) and factory (Commodity Chemical Factory of Guilin city), respectively, and filtered before analysis. A $100 \mu \mathrm{L}$ of the sample was measured 
according the procedure. At the same time, the samples were also analyzed with the $\mathrm{Fe}(\mathrm{II})$ ortho-phenylene diamine catalytic spectrophotometric method [11]. The results of both the methods are listed in Table 1 . The linear regression analysis revealed a correlation coefficient, slope, and intercept of $0.9997,0.9759$, and $0.0568 \mu \mathrm{M}$, respectively. This showed that the RS results were in good agreement with that of the spectrophotometric method, and both methods have good correlation. A $1.30 \mu \mathrm{M}, 0.250 \mu \mathrm{M}$ and $5.00 \mu \mathrm{M} \mathrm{H}_{2} \mathrm{O}_{2}$ were added in the sample 1, 2 and 3, respectively. Then it was analyzed according to the procedure. The recoveries were in the range of 98.0-104\%. The results indicated that this enzyme catalytic RS assay is accurate and reliable. From Table 1, we can see that the $\mathrm{H}_{2} \mathrm{O}_{2}$ content of this assay is lowest in rural rain water sample owing to the least environmental pollution, the $\mathrm{H}_{2} \mathrm{O}_{2}$ content is highest in the place of factory that one reason may be serious pollution, and the content of urban sample locates the both samples. Table 1 also showed that this assay results were agreement with that of the reference results.

Table 1. Analytical results.

\begin{tabular}{|c|c|c|c|c|c|}
\hline Sample & $\begin{array}{c}\text { Results of this assay } \\
(\mu \mathrm{M}, \mathrm{n}=5)\end{array}$ & $\begin{array}{c}\text { Added } \\
(\mu \mathrm{M})\end{array}$ & $\begin{array}{c}\text { Found } \\
(\mu \mathrm{M})\end{array}$ & $\begin{array}{c}\text { Recovery } \\
(\%)\end{array}$ & $\begin{array}{c}\text { Reference results [11] } \\
(\mu \mathrm{M}, \mathrm{n}=5)\end{array}$ \\
\hline Sample 1 & $1.336 \pm 0.069$ & 1.30 & 1.35 & 104 & $1.280 \pm 0.071$ \\
\hline Sample 2 & $0.273 \pm 0.012$ & 0.250 & 0.256 & 102 & $0.270 \pm 0.011$ \\
\hline Sample 3 & $5.006 \pm 0.144$ & 5.00 & 4.95 & 98.0 & $5.084 \pm 0.125$ \\
\hline
\end{tabular}

\section{CONCLUSIONS}

Based on the catalytic effect of horseradish peroxidase on the particle reaction between guaiacol and $\mathrm{H}_{2} \mathrm{O}_{2}$, and the RS effect of the organic particles, a new, sensitive, selective and rapid enzyme catalytic RS assay was proposed for the determination of $0.55-27.6 \mu \mathrm{M} \mathrm{H}_{2} \mathrm{O}_{2}$.

\section{ACKNOWLEDGMENTS}

This work was supported by the National Natural Science Foundation of China (Nos. 21075023, 20865002, 20965002), Natural Science Foundation of Guangxi (No.0991021z) and the Research Funds of Key Laboratory of Ecology of Rare and Endangered Species and Environmental Protection (Guangxi Normal University), Ministry of Education.

\section{REFERENCES}

1. Liu, P.T. Introduction to Environmental Science, Higher Education Press: Beijing; 1995; p 29.

2. Zhang, Z.Y.; Liang, W.A. Phys. Test. Chem. Anal. Part B 2000, 36, 5.

3. Ma, N.; Ma, Z.; Yue, Y.H.; Gao, Z. J. Mol. Catal. A 2002, 184, 361.

4. Yue, H.F.; Bu, X.; Huang, M.H.; Young, J.; Raglione, T. Pharmaceutics 2009, 22, 33.

5. Zhou, G.J.; Wang, G.; Xu, J.J.; Chen, H.Y. Sensors and Actuators B 2002, 81, 334.

6. Tahirović, A.; Čopra, A.; Omanović-Mikličanin, E.; Kalcher, K. Talanta 2007, 72, 1378.

7. Abbas, M.E.; Luo, W.; Zhu, L.; Zou, J.; Tang, H.Q. Food Chem. 2010, 120, 327.

8. Akio, S.; Tetsuyuki, T.; Tadao, O. Anal. Chim. Acta 1998, 374, 191.

9. Wang, M.L. Jiangsu Environ. Sci. Technol. 2001, 14, 7.

10. Jiang, Z.L.; Tang, Y.F.; Liang, A.H.; Gong, Q. Spect. Spect. Anal. 2009, 29, 1990.

11. Liang, A.H.; Wang, N. J. Guilin Univ. Techn. 2007, 27, 402.

Bull. Chem. Soc. Ethiop. 2011, 25(2) 
12. Hellpointner, E.; Gäb, S. Nature 1989, 337, 631.

13. Pappas, A.C.; Stalikas, C.D.; Fiamegos, Y.C.; Karayannis, M.I. Anal. Chim. Acta 2002, 455, 305.

14. Sun, Y.X.; Zhang, J.T.; Huang, S.W.; Wang, S.F. Sensors and Actuators B 2007, 124, 494.

15. Li, Z.Z. Jiang, Z.L.; Yang, G.; Lu, D.; Liu, S.P. Spect. Spect. Anal. 2005, 25, 1286.

16. Jiang, Z.L.; Ma, J.; Liang, A.H.; Li, J.S. Acta Chim. Sin. 2008, 66, 1985.

17. Pastemack, R.F.; Bustamante, C.; Collings, P.J.; Giannetto, A.; Gibbs, E.J. J. Am. Chem. Soc. 1993, 115, 5393.

18. Liu, S.P.; Luo, H. Q.; Li, N.B.; Liu, Z.F.; Zheng, W.X. Anal. Chem. 2001, 73, 3907

19. Huang, C.Z.; Li, K.A.; Tong, S.Y. Anal. Chem. 1996, 68, 2259.

20. Jiang, Z.L.; Zhou, S.M.; Liang, A.H.; Kang, C.Y.; He, X.C. Environ. Sci. Technol. 2006, 40, 4286.

21. Jiang, Z.L.; Fan, Y.Y.; M.L. Chen, A.H. Liang, X.J. Liao, G.Q. Wen, X.C. Shen, X.C. He, H.C. Pan, Jiang, H.S. Anal. Chem. 2009, 81, 5439.

22. Jiang, Z.L.; Li, J.F.; Liang, A.H.; Li, J.S.; Tang, Y.F.; Wang, S.M.; Zhang, N.N. Chem. J. Chin. Univ. 2008, 29, 1973.

23. Liang, A.H.; Jiang, B.; Ma, J.; Jiang, Z.L.; Li, J.S. J. Fluoresc. 2008, 18, 1059.

24. Zhang, J.M.; Dong, Y.X.; Du, Y.M.; Li, Y.Q. J. Hebei Univ. 2004, 24, 277. 